\title{
Human Papillomavirus and Squamous Cell Carcinoma of Unknown Primary in the Head and Neck Region: A Comprehensive Review on Clinical Implications
}

\author{
Mikkel Hjordt Holm Larsen*D, Hani Ibrahim Channir and Christian von Buchwald \\ Department of Otorhinolaryngology, Head and Neck Surgery \& Audiology, Rigshospitalet, \\ Copenhagen University Hospital, 2100 Copenhagen, Denmark; Hani.Ibrahim.Channir.02@regionh.dk (H.I.C.); \\ christian.von.buchwald@regionh.dk (C.v.B.) \\ * Correspondence: mikkel.hjordt.holm.larsen@regionh.dk
}

Citation: Larsen, M.H.H.; Channir, H.I.; von Buchwald, C. Human Papillomavirus and Squamous Cell Carcinoma of Unknown Primary in the Head and Neck Region: A Comprehensive Review on Clinical Implications. Viruses 2021, 13, 1297. https://doi.org/10.3390/v13071297

Academic Editor: Ian N. Hampson

Received: 4 June 2021

Accepted: 29 June 2021

Published: 2 July 2021

Publisher's Note: MDPI stays neutral with regard to jurisdictional claims in published maps and institutional affiliations.

Copyright: (c) 2021 by the authors. Licensee MDPI, Basel, Switzerland. This article is an open access article distributed under the terms and conditions of the Creative Commons Attribution (CC BY) license (https:// creativecommons.org/licenses/by/ $4.0 /)$.
Abstract: Squamous cell carcinoma of unknown primary (SCCUP) is a challenging diagnostic subgroup of oropharyngeal squamous cell carcinoma (OPSCC). The incidence of SCCUP is increasing in parallel with the well-documented increase in OPSCC and is likewise driven by the increase in human papillomavirus (HPV). The SCCUP patient often presents with a cystic lymph node metastasis and undergoes an aggressive diagnostic and treatment program. Detection of HPV in cytologic specimens indicates an oropharyngeal primary tumor origin and can guide the further diagnostic strategy. Advances in diagnostic modalities, e.g., transoral robotic surgery and transoral laser microsurgery, have increased the successful identification of the primary tumor site in HPV-induced SCCUP, and this harbors a potential for de-escalation treatment and increased survival. This review provides an overview of HPV-induced SCCUP, diagnostic modalities, and treatment options.

Keywords: human papillomavirus; head and neck cancer; unknown primary; cervical lymph node metastasis

\section{Introduction}

Annually, more than 90,000 people are diagnosed with oropharyngeal squamous cell carcinoma (OPSCC) worldwide [1]. A subgroup of OPSCC is seen among patients referred with a cervical lymph node metastasis as the primary symptom of malignant disease and where the primary tumor site cannot be identified, hence named squamous cell carcinoma of unknown primary (SCCUP). Patients with SCCUP are estimated to represent up to $10 \%$ of the OPSCC cases annually [2]. In parallel with the sharp increase in the incidence of OPSCC, there has been an escalation of patients with SCCUP which is reported to be linked to the significant increase in human papillomavirus (HPV)-induced OPSCC [3-6]. The diagnostic workup of SCCUP is laborious and often includes a clinical examination and radiologic imaging, i.e., whole body positron emission tomography-computed tomography (PET-CT) or magnetic resonance imaging (MRI) [7-9]. If the primary tumor site is not identified, the patient is hereafter referred to pan-endoscopy under general anesthesia with concurrent random or targeted biopsies from the base of the tongue, bilateral palatine tonsillectomy and adenoidectomy, and, in some institutions, transoral robotic surgery (TORS)- or transoral laser microsurgery (TLM)-assisted lingual mucosectomy [7-9]. However, the diagnostic algorithm is diverse and remains controversial across institutions and countries, with no uniform consensus and conflicting treatment strategies, as demonstrated by a Nordic survey [10]. If the diagnostic workup fails to identify the primary tumor site, the patient is diagnosed with and subsequently treated for SCCUP. The current treatment approach at the early N-site stage is neck dissection, if deemed technically possible, or definitive radiotherapy (RT) $[7,8,11]$. With an advanced cancer stage (i.e., solely based on $\mathrm{cN} / \mathrm{pN}$ ), patients are referred to the traditional first-line treatment with (chemo)radiotherapy (CRT) $[7,8,11]$ which often involves wide-field bilateral 
IMRT radiotherapy of the neck with total mucosal irradiation $[8,11,12]$. This may lead to a successive quality of life (QoL) decline in domains such as xerostomia, dysphagia, and chewing ability, as demonstrated among OPSCC patients [13-16].

In parallel with the increasing numbers of SCCUPs induced by HPV, HPV testing of the cervical lymph node metastasis is increasingly applied as a part of the diagnostic workup [17]. HPV detection substantiates the suspicion of OPSCC located in the palatine or lingual tonsils [18] and may further guide the diagnostic workup and treatment and serve as an essential prognostic tool [19].

The aim of this review is to provide an overview of HPV-induced SCCUP, including diagnostic workup strategies for the primary tumor and different treatment options in HPV-induced SCCUP patients.

\section{Development of HPV SCCUP}

HPV is a widespread sexually transmitted disease, e.g., it is the most common sexually transmitted disease in the United States [20], and in the case of OPSCC, it is thought to transmit through genito-oral and oral-anal sexual contact [21]. In the western world, OPSCCs are reported to be caused by HPV in the majority of patients, and there was an upsurge of HPV-induced OPSCC in the United States from 16\% in the 1980s to more than $70 \%$ during the 2000s [22]. The high incidence of HPV-induced OPSCC is also seen in a number of European countries, with an increase from 35\% before 2000 to $73 \%$ after 2005 [23], whereas HPV positivity in Asia is reported to occur in 20-34\% of OPSCCs [24-27] with an increasing incidence $[24,25,27]$.

A substantial number of primary tumors identified in SCCUP patients are found in the oropharynx and are HPV-induced, with HPV16 being the predominant high-risk subtype $[23,28,29]$. The demographic and clinical traits of OPSCC and SCCUP are quite similar. The majority of HPV-positive (+) patients are often males, younger than HPVnegative (-) patients, and tend to exhibit less alcohol and tobacco abuse $[5,6,30]$, which are common causes of HPV disease [31,32]. Both groups often exhibit a cystic lymph node metastasis and an early T-stage, which are also the instances when the primary tumor site is identified in SCCUP [6,33-36]. However, what constitutes the biological differences between SCCUP and OPSCC and causes a small, undetectable primary tumor or regressed tumor to metastasize early to the regional lymph nodes is unknown and still debatable.

HPV is a double stranded DNA virus that integrates with the host genome in the cell nuclei where transcription of E6 and E7 carcinogenic proteins is activated [37,38]. The transcription of viral carcinogenic proteins, e.g., E6 and E7, in the tumor cell nuclei causes carcinogenesis by interaction with and degradation of the host protein, p53, and inactivation of retinoblastoma protein, both major tumor-suppressor proteins [37-39]. This leads to an overexpression of p16, a cyclin-dependent kinase inhibitor often used as a surrogate marker for HPV-positivity [7,8,39]. This overexpression is reflected by the latest update of the 8th edition of the AJCC cancer staging manual in which staging of the cancer is based upon p16 status due to the excellent treatment response and better prognosis in HPV+ patients [40,41]. It is believed that a persistent infection with HPV is the key component of carcinogenesis and the development into OPSCC [38], which has been well described in HPV-induced cervical cancer with HPV16 being the predominant subtype [20]. One study analyzed antibodies against HPV16 in serum samples stored for almost 10 years before OPSCC was diagnosed and demonstrated a 14-fold increase in the risk of developing OPSCC among those displaying seropositivity [42].

Within the oropharynx, a specialized reticulated lymphoepithelial mucosal tissue is found in the crypts of the palatine and lingual tonsils, which are particularly susceptible to HPV infection [28] and take part in immune response initiation [37,43]. The epithelium is also characterized by intraepithelial blood vessels and a discontinuous basal membrane, which could allow for the early metastasis tendency from even small occult tumors to the cervical lymph nodes $[28,44]$. An immune-mediated response has also been proposed to cause tumor regression [45] and is supported by in vivo and in vitro models reflecting the 
antitumor and tumor clearance response from CD4+ and CD8+ cells [46]. High counts of CD8+ tumor-infiltrating lymphocytes have likewise been shown to possess a favorable prognostic outcome in patients [47-49], emphasizing the possible immune-mediated component in tumor regulation $[48,49]$.

In contrast to HPV, tobacco use causes direct DNA damage and formation of oncogenic DNA adducts that can be traced in human tissue, as also demonstrated in head and neck cancer [50]. Smoking also causes double stranded DNA breaks in the cell, and the inability to repair these DNA damages has been associated with squamous cell carcinoma development [51].

\section{Identification of the Primary Tumor Site Addressing HPV}

A rigorous and aggressive diagnostic workup program is normally accomplished in order to successfully identify the primary tumor and includes thorough physical examination, fine needle aspiration (FNA), radiologic examinations, and examination under general anesthesia $[7,8,11]$.

\subsection{Fine Needle Aspiration}

As patients with HPV+ SCCUP often present with an enlarged cervical lymph node, it is imperative to discriminate between underlying malignancy and benign conditions, e.g., branchial cleft cysts. This evaluation can be performed using an FNA from the lymph node, since radiologic imaging is insufficient in distinguishing between a branchial cleft cyst and the cystic metastasis from HPV+ SCCUP [52]. FNA has been proven as a cost-effective diagnostic tool and a suitable method for molecular testing on preserved DNA [53], and there is no significant difference in the diagnostic rates of cancers such as squamous cell carcinoma, adenocarcinoma, or thyroid carcinoma when compared to core needle sampling [54]. Several HPV testing assays have been validated in cytology specimens and have been shown to be feasible and effective in guiding the diagnostic workup of patients with SCCUP [18,36,55-59]. In addition, FNA is a more reliable tool for identifying the primary in comparison with PET-CT [60]. If HPV is detected in the FNA smear, it substantiates the suspicion of oropharyngeal primary tumor origin $[36,58]$. HPV-DNA testing can be performed by PCR with a sensitivity of $95 \%$ and specificity of $100 \%$ or in situ hybridization with a sensitivity and specificity of $91 \%$ and $94 \%$, respectively $[18,29]$, with an excellent concordance between HPV status of the cervical metastasis and identified primary tumors [12]. p16-positive (+) immunocytochemistry has similarly been proposed as a surrogate marker for HPV+ with a reasonable concordance with HPV-DNA/mRNA detection, but the technique has a notable inferior specificity $[29,61]$ and is currently widely debated in terms of determining a cutoff criterion for p16 staining [18]. The technique additionally carries a risk of false positivity in benign conditions, e.g., branchial cleft cysts [43,62]. An estimated 10-15\% of OPSCC and SCCUP exhibit p16+ but HPV-DNA negativity $[35,63,64]$, and p16 should, therefore, not be used as a basis for de-escalation treatment decisions. This is supported by large cohort studies proving that solely the combination of HPV+ and p16+, compared to p16+ alone, warrants improved survival and minimized risk of distant metastasis [35,65].

\subsection{Radiological Examination}

The radiological examinations used are typically CT or MRI, both providing identical reported primary tumor identification rates of 9-23\% [17,60], disregarding HPV status, with MRI being superior in determining extracapsular nodal extension (ECE) [17]. PET-CT is reported as giving identification rates of $29-44 \%[60,66]$ and as having a sensitivity and a specificity of $73-97 \%$ and $44-68 \%$, respectively $[66,67]$, but with no information on HPV status correlation. A study from the Netherlands $(n=31)$ found that there was no significant association between p16 and HPV status and imaging results [68]. PET-CT has a high false-positive rate due to the physiological uptake of the tracer in normal lymphoid tissue in the Waldeyer's lymphatic ring [34,69,70]. The combined functional (PET) and CT 
examination has an inability to identify small tumors under 5 to $10 \mathrm{~mm}$ in diameter [17,71], which is a striking issue in the event of SCCUP diagnostics where identified primary sites are reported with a mean size of $0.78-1.3 \mathrm{~cm}[12,72-74]$.

In OPSCC, where the tumor is successfully visualized on CT scans, it is hypothesized that the modality is able to distinguish between HPV - and HPV+. This is because HPVtumors are significantly more often invading the adjacent pharyngeal musculature than HPV+ tumors [75], and HPV+ tumors are more often seen as exophytic tumors with clearly defined borders, although this is not statistically significant [75]. The HPV+ cases were, however, significantly more likely to exhibit cystic nodal metastases than HPVtumors [75], which can be translated to SCCUP since cystic morphology is a common trait in both SCCUP and OPSCC [59]. Recently, in a hypothesis-generating study, a deep learning algorithm of PET-images was able to successfully distinguish between HPV+ and HPV-OPSCC disease with an AUC of 0.83 [76]. Future radiological imaging in SCCUP will most likely benefit from possible deep learning algorithms. Transcervical ultrasound has also been introduced in the diagnostic workup, and in an unblinded prospective cohort study including 51 patients with suspected or confirmed OPSCC, it correctly identified $90.2 \%$ of the tumors and identified 10/14 tumors that were missed by CT [77]. However, with $n=47$ being p16+, the study unfortunately did not reveal how many of the patients were classified as SCCUP before enrolment, but the average dimension of identified tumors was $2.3 \mathrm{~cm}$ [77].

\subsection{Surgical Procedures}

After radiological imaging and clinical examination, the patient is normally scheduled for an examination under general anesthesia (pan-endoscopy). The identification rate is $22-31 \%$ after direct pharyngo-laryngoscopy [9,78,79], 28-30\% after palatine tonsillectomy [9,80,81], and $18 \%$ after base of the tongue biopsies [82]. It is noteworthy that the cumulative identification rate differs remarkedly in HPV - and HPV+ patients, with reported cumulative identification rates of $26 \%$ versus $65 \%$, respectively [9].

An addition to the clinical examination of SCCUP patients in the pursuit of successful primary tumor site identification is narrow band imaging (NBI). The endoscopic tool can visualize neo-angiogenic formations that are characteristic of malignant tumors by restricted light wavelength. In a recent meta-analysis comprising SCCUP patients, the use of NBI showed a sensitivity and specificity of $83 \%$ and $88 \%$, respectively, and the overall identification rate was 35\%, disregarding HPV status which was not reported [83].

In 2009, the FDA approved the use of TORS for early-stage OPSCC [84]. The procedure has, correspondent to the surge in HPV-induced OPSCC, been increasingly adopted in surgical oncological treatment, with an increase of $67 \%$ in the United States in the early 2010s, especially in the treatment of HPV+ cancer [85]. The use of TORS in HPV+ disease was further shown to be associated with reduced likelihood of adjuvant CRT versus adjuvant radiotherapy, and the risk of positive margins was significantly reduced when comparing TORS with conventional surgery [85].

The utility of TORS and TLM-assisted lingual mucosectomy has also been proven as a new diagnostic modality for SCCUP patients, with successful identification rates of 70-78\% of the primary tumor sites [34,86-88]. These diagnostic modalities provide improved visualization and access to an anatomically complex area, and freedom of movement compared to conventional surgical techniques when resecting the superficial part of the tongue base [34], and are therefore advancing as essential diagnostic tools in SCCUP. The procedure is, as also proven in previous diagnostic steps, highly effective in identifying the primary tumor site in the group of patients with HPV+ lymph node metastasis, as 55-96\% of the identified tumors are HPV $+[87,88]$. This is contrasted by an identification rate of only $13 \%$ in HPV - cases [89]. The procedure consequently entails improved tumor detection in HPV+ cases with the potential for radical surgical treatment when the tumor site is identified. Even when there is an indication for adjuvant medical oncological treatment, 
the identification of the primary tumor site effectuates a notable volume reduction in the adjuvant RT and hence de-escalates oncological treatment [9,90,91].

Synchronous tumors have been demonstrated to occur in $6-18 \%$ of palatine and lingual tonsil cancers $[9,64,80,81,91,92]$. The rate of synchronous cancers in HPV+ cases is reported by two studies, one of which found a rate of $7.7 \%$ in HPV+ patients with SCCUP [91], while a second found a rate of $5 \%$ among SCCUP patients where $92 \%$ of the synchronous tumors were HPV+, with the highest incidence in the mid-2000s and early 2010s [92]. Nevertheless, the literature regarding the frequency of synchronous tumors conflicts with other studies reporting a lower risk of synchronous primary tumors with p16+ [93] and an incidence of synchronous or metachronous OPSCC between $0.5 \%$ and $2.5 \%$ [94]. However, the authors found a prevalence from $1 \%$ to $10 \%$ when pooling patients with both HPV+ and unknown HPV status [94]. Given the lack of evidence and conflicting prevalence, a bilateral mucosectomy approach should strongly be considered due to the high rate, between $2 \%$ and $15 \%$, of contralateral disease in the palatine and lingual tonsils in studies with $71-82 \% \mathrm{HPV}+$ cases $[34,86,95]$.

\section{Treatment}

Referring to a European multi-center study, HPV+ SCCUP generally possesses a better prognosis than its HPV - counterparts, with significantly better overall survival and progression-free survival [32]. A Swedish cohort study also found an increased 2-, $5-$, and 10 -year survival of $93 \%, 88 \%$, and $82 \%$, respectively, for p16+ SCCUP versus a $67 \%, 61 \%$, and 39\% 2-, 5- and 10-year survival, respectively, for p16- SCCUP [96]. A recent meta-analysis of SCCUP also found a better survival in HPV+ disease, with 5-year overall survival of $91 \%$ compared to $44 \%$ overall survival with HPV- disease [19]. This improved survival is in accordance with the significantly better survival recorded in OPSCC disease, especially in the case of both HPV+ and p16+ [35,97].

The identification of the primary tumor site is mandated for an optimal treatment.

A retrospective study $(n=136)$ has highlighted the importance of identifying the primary tumor site as this leads to improved overall survival, cause-specific survival, and disease-free survival, also when stratified for HPV status [98]. The adjuvant RT is altered for targeted therapy with a reduced RT volume and RT field after identification of the primary $[9,90,91,99]$. In retrospective studies with $92-100 \% \mathrm{HPV}+$ cohorts, it is demonstrated that between $25 \%$ and $30 \%$ of the patients can be treated solely with TLM or TORS [72,100-102]. In one cohort study including p16+ patients and another including $>66 \% \mathrm{HPV}+$ patients, it has been proposed that the pharyngeal mucosa can be sparred in $44-50 \%$ of the patients $[91,102]$, thereby limiting multimodal therapy. Even after a failed primary tumor site identification, there is no difference in overall, local and distant, or regional recurrence-free survival when omitting the pharyngeal mucosa in the RT field for p16+ patients after a thorough diagnostic workup including TORS with clearance of the lymphoid tissue in the oropharynx [103]. The de-escalation strategy significantly limited grade $2+$ mucositis, opioid treatment, weight loss, feeding tube placement, and unplanned hospital admissions [103].

Recent literature also suggests that ECE in the case of HPV+ does not signify the same risk of an inferior treatment outcome as its HPV - counterpart. A recent study $(n=82)$ from Ireland has demonstrated that ECE in association with p16+ does not significantly influence recurrence-free survival and disease-free survival when the majority of patients received adjuvant RT [104], and the use of adjuvant CRT therapy might, therefore, be questioned. Similar results have also been demonstrated among p16+ OPSCC patients $[105,106]$.

Furthermore, a retrospective database study from the Commission on Cancer National Cancer Database in the United States $(n=978)$ demonstrated that cN2 and cN3 HPV+ patients had similar survival regardless of treatment choice, be that surgery, surgery with adjuvant RT, or surgery with adjuvant CRT or definitive CRT or definitive RT on multivariate analysis, while de-escalation therapy in HPV - patients was associated with worse outcome [107]. 
De-escalated therapy may therefore be an option selected for HPV+ SCCUP. However, the efficacy assessment of a de-escalation therapy strategy requires long follow-up periods and is still awaited.

\section{Discussion}

The risk of HPV infection during a lifetime is striking, as most sexually active persons will acquire the infection at some point [108]. The HPV infection can be cleared and only exist transiently, but if persistent, it can be oncogenic [109], with subsequent risk of developing OPSCC [42].

The frequency of SCCUP has significantly increased in recent decades, as illustrated by a single-institution study from the United States in which the mean number of SCCUP cases increased from 3.5 per year in 2005-2008 to 15.6 per year in 2012-2014, in parallel with optimized diagnostic primary tumor-detection rates after implantation of TORS [5]. A large Danish cohort study also observed a significant rise in palatine tonsil and base of tongue cancers from 2000 to 2017, and the surge in base of tongue cancers is speculated to be originating from increased use of TORS tongue-base mucosectomy in patients with SCCUP [6].

HPV status has been added to the latest 8th edition of the AJCC cancer staging manual, since there is a distinct difference between HPV+ and HPV - cases and the prognosis. The superior survival, especially in HPV+ and p16+ OPSCC patients, makes this patient category particularly suitable for de-escalation trials [35]. The distinction between HPV+ and HPV - patients has also been shown to reflect the patient's comorbidity burden. From a large population-based study, it is demonstrated that HPV+ patients had significantly fewer comorbidities, both at the time of diagnosis and throughout the subsequent treatment, compared to HPV - patients, and that HPV - patients also had a higher occurrence of multiple comorbidities, e.g., cerebrovascular disease, other malignancy, and dementia [110]. This is also evident in a study where, e.g., cerebrovascular disease was significantly lower among patients with HPV+ disease [111]. For this reason, it is mandatory to determine the correct HPV status of the lymph node metastasis due to the potential implications it harbors for guidance in diagnostics and treatment, as this can lead to a more personalized paradigm in favor of the patients, clinicians, and healthcare system.

Failure to identify the primary tumor despite extensive diagnostic workups may reflect the small tumor size located deep in the tonsillar crypts, or it may be a question of an immune-mediated response, as the immune system has been demonstrated to be active in combatting HPV+ OPSCC $[28,37,44,46,48,49]$. A key point in the identification of the primary tumor is the thorough histological examination of the resected specimen, whether palatine or lingual tonsils, performed by the pathologist. An ongoing study aims to evaluate the feasibility and identification-rate of step serial sectioning versus conventional histology of the resected tongue base biopsy and palatine tonsils, with the hope of increased detection rates of the primary tumor site that would otherwise have been missed by the conventional histological technique (NCT04151134).

Given the better prognosis and possibility of de-escalation therapy with HPV+, several ongoing trials are aiming to tailor and reduce RT (NCT04489212, NCT02764216, NCT03323463). However, the relatively few annual SCCUP patients and the diverse diagnostic and treatment modalities used across institutions are limiting the possibilities of a multi-center, multi-national, and randomized clinical trial.

The addition of TORS and TLM as a new diagnostic and treatment modality has proven a useful and highly effective tool in the search for the primary tumor. In several trials, the identification rate has increased with the addition of TORS and TLM-assisted lingual mucosectomy compared to traditional diagnostic approaches $[5,9,34,112]$. The TORS procedure also allows for complete surgical, oncologic lingual mucosectomy with negative margins in $60-80 \%$ of the cases $[87,88]$. One ongoing study from Canada is pursuing the successful identification of SCCUP with TORS among T0, N1-N3, and M0 patients and possible de-intensified adjuvant RT therapy (NCT03281499) but could be 
limited by its small sample size $(n=22)$ and recruitment not limited by HPV status, yet similar designs should be implemented as a research purpose at multiple institutions. TORS has been proven as a safe procedure with limited effect on QoL $[34,113,114]$; however, one of the primary reasons for unplanned readmission following TORS is pain [115]. This is being investigated in an ongoing Danish national randomized clinical trial assigning patients to either a high-dose or low-dose dexamethasone treatment regime following TORS (NCT04189107) [116]. Future research should assess QoL and functional outcomes when comparing treatment approaches. In OPSCC, this is applied in the comparison of TORS and CRT, e.g., the ongoing Danish randomized clinical trial (NCT04124198, quality of life after primary TORS vs IMRT "The QoLATI study" DAHANCA-34). These QoL and functional evaluations combined with patient-related but objective measurements such as days alive and out of hospital, which is a patient-related outcome metric that reflects the burden of a given disease but also the treatment offered [116], should be implemented in upcoming treatment-comparing studies.

In conclusion, HPV+ SCCUP is a challenging disease entity for patients, clinicians, and researchers with a lack of consensus regarding diagnostic procedures, treatment, and understanding of the pathophysiology in disease development. Fortunately, awareness is increasing as indicated by the recent 8th AJCC cancer staging manual classifying SCCUP based on HPV status rather than a uniform disease entity, as it was considered up until recently. Different diagnostic workup algorithms and treatment options should also be based on HPV status. The HPV-induced SCCUP disease could be seen as a subgroup of OPSCC, but with a tumor so small that it is missed during radiological imaging and histological examinations of resected specimens, supported by the observed increase in identification rates with the implementation of advanced modalities as TORS, TLM, and PET-CT. Several ongoing trials are aiming at optimizing diagnostics and treatment modalities, but given the rarity of the condition, the advancement must, so far, be reliant on retrospective and prospective cohort studies.

Author Contributions: Original draft preparation, M.H.H.L.; writing—review and editing, H.I.C. and C.v.B. All authors have read and agreed to the published version of the manuscript.

Funding: This research was funded by non-profit organization Candys Foundation under Grant 2019-304, The Capital Region of Denmark under Grant A6682.

Institutional Review Board Statement: Not applicable.

Informed Consent Statement: Not applicable.

Conflicts of Interest: The authors declare no conflict of interest.

\section{References}

1. Bray, F.; Ferlay, J.; Soerjomataram, I.; Siegel, R.L.; Torre, L.A.; Jemal, A. Global cancer statistics 2018: GLOBOCAN estimates of incidence and mortality worldwide for 36 cancers in 185 countries. CA Cancer J. Clin. 2018, 68, 394-424. [CrossRef]

2. Jereczek-Fossa, B.A.; Jassem, J.; Orecchia, R. Cervical lymph node metastases of squamous cell carcinoma from an unknown primary. Cancer Treat. Rev. 2004, 30, 153-164. [CrossRef]

3. Garnaes, E.; Kiss, K.; Andersen, L.; Therkildsen, M.H.; Franzmann, M.B.; Filtenborg-Barnkob, B.; Hoegdall, E.; Krenk, L.; Josiassen, M.; Lajer, C.B.; et al. A high and increasing HPV prevalence in tonsillar cancers in Eastern Denmark, 2000-2010: The largest registry-based study to date. Int. J. Cancer 2015, 136, 2196-2203. [CrossRef]

4. Garnaes, E.; Kiss, K.; Andersen, E.; Therkildsen, M.H.; Franzmann, M.B.; Filtenborgbarnkob, B.; Hoegdall, E.; Lajer, C.; Specht, L.; Joenson, L.; et al. Increasing incidence of base of tongue cancers from 2000 to 2010 due to HPV: The largest demographic study of 210 Danish patients. Br. J. Cancer 2015, 113, 131-134. [CrossRef]

5. Motz, K.; Qualliotine, J.R.; Rettig, E.; Richmon, J.D.; Eisele, D.W.; Fakhry, C. Changes in Unknown Primary Squamous Cell Carcinoma of the Head and Neck at Initial Presentation in the Era of Human Papillomavirus. JAMA Otolaryngol. Neck Surg. 2016, 142, 223-228. [CrossRef]

6. Zamani, M.; Grønhøj, C.; Jensen, D.H.; Carlander, A.F.; Agander, T.; Kiss, K.; Olsen, C.; Baandrup, L.; Nielsen, F.C.; Andersen, E.; et al. The current epidemic of HPV-associated oropharyngeal cancer: An 18-year Danish population-based study with 2,169 patients. Eur. J. Cancer 2020, 134, 52-59. [CrossRef] [PubMed] 
7. Maghami, E.; Ismaila, N.; Alvarez, A.; Chernock, R.; Duvvuri, U.; Geiger, J.; Gross, N.; Haughey, B.; Paul, D.; Rodriguez, C.; et al. Diagnosis and Management of Squamous Cell Carcinoma of Unknown Primary in the Head and Neck: ASCO Guideline. J. Clin. Oncol. 2020, 38, 2570-2596. [CrossRef] [PubMed]

8. MacKenzie, K.; Watson, M.; Jankowska, P.; Bhide, S.; Simo, R. Investigation and management of the unknown primary with metastatic neck disease: United Kingdom National Multidisciplinary Guidelines. J. Laryngol. Otol. 2016, 130, S170-S175. [CrossRef]

9. Ryan, J.F.; Motz, K.M.; Rooper, L.M.; Mydlarz, W.K.; Quon, H.; Gourin, C.G.; Tan, M.; Eisele, D.W.; Fakhry, C. The Impact of a Stepwise Approach to Primary Tumor Detection in Squamous Cell Carcinoma of the Neck With Unknown Primary. Laryngoscope 2019, 129, 1610-1616. [CrossRef]

10. Farnebo, L.; Laurell, G.; Mäkitie, A. A Nordic survey on the management of head and neck CUP. Acta Oto-Laryngol. 2016, 136, 1159-1163. [CrossRef]

11. DAHANCA. DAHANCA National Guidlines Regarding Carcinoma of Unknown Primary. 2013. Available online: https: //www.dahanca.oncology.dk/assets/files/GUID_Ukendt\%20primaertumor.pdf (accessed on 1 June 2021).

12. Channir, H.I.; Rubek, N.; Nielsen, H.U.; Kiss, K.; Charabi, B.W.; Lajer, C.B.; von Buchwald, C. Transoral robotic surgery for the management of head and neck squamous cell carcinoma of unknown primary. Acta Oto-Laryngol. 2015, 135, 1051-1057. [CrossRef]

13. Michaelsen, S.H.; Grønhøj, C.; Michaelsen, J.H.; Friborg, J.; von Buchwald, C. Quality of life in survivors of oropharyngeal cancer: A systematic review and meta-analysis of 1366 patients. Eur. J. Cancer 2017, 78, 91-102. [CrossRef] [PubMed]

14. Roets, E.; Tukanova, K.; Govarts, A.; Specenier, P. Quality of life in oropharyngeal cancer: A structured review of the literature. Support. Care Cancer 2018, 26, 2511-2518. [CrossRef] [PubMed]

15. Machtay, M.; Moughan, J.; Trotti, A.; Garden, A.; Weber, R.S.; Cooper, J.S.; Forastiere, A.A.; Ang, K.K. Factors Associated With Severe Late Toxicity After Concurrent Chemoradiation for Locally Advanced Head and Neck Cancer: An RTOG Analysis. J. Clin. Oncol. 2008, 26, 3582-3589. [CrossRef] [PubMed]

16. Scott, S.I.; Kathrine Ø Madsen, A.; Rubek, N.; Charabi, B.W.; Wessel, I.; Fredslund Hadjú, S.; Jensen, C.V.; Stephen, S.; Patterson, J.M.; Friborg, J.; et al. Long-term quality of life \& functional outcomes after treatment of oropharyngeal cancer. Cancer Med. 2021, 10, 483-495.

17. Golusinski, P.; Di Maio, P.; Pehlivan, B.; Colley, S.; Nankivell, P.; Kong, A.; Hartley, A.; Mehanna, H. Evidence for the approach to the diagnostic evaluation of squamous cell carcinoma occult primary tumors of the head and neck. Oral Oncol. 2019, 88, 145-152. [CrossRef]

18. Channir, H.I.; Larsen, C.G.; Msc, L.B.A.; Hansen, T.V.O.; Gerds, T.A.; Charabi, B.W.; Vainer, B.; Von Buchwald, C.; Lajer, C.B.; Kiss, K. Validation study of HPV DNA detection from stained FNA smears by polymerase chain reaction: Improving the diagnostic workup of patients with a tumor on the neck. Cancer Cytopathol. 2016, 124, 820-827. [CrossRef]

19. Ren, J.; Yang, W.; Su, J.; Ren, X.; Fazelzad, R.; Albert, T.; Habbous, S.; Goldstein, D.P.; De Almeida, J.R.; Hansen, A.; et al. Human papillomavirus and p16 immunostaining, prevalence and prognosis of squamous carcinoma of unknown primary in the head and neck region. Int. J. Cancer 2019, 145, 1465-1474. [CrossRef]

20. Schiffman, M.; Castle, P.E. Human papillomavirus: Epidemiology and public health. Arch. Pathol. Lab. Med. 2003, 127. [CrossRef]

21. Pai, S.I.; Westra, W.H. Molecular Pathology of Head and Neck Cancer: Implications for Diagnosis, Prognosis, and Treatment. Annu. Rev. Pathol. Mech. Dis. 2009, 4, 49-70. [CrossRef]

22. Chaturvedi, A.K.; Engels, E.A.; Pfeiffer, R.M.; Hernandez, B.Y.; Xiao, W.; Kim, E.; Jiang, B.; Goodman, M.T.; Sibug-Saber, M.; Cozen, W.; et al. Human Papillomavirus and Rising Oropharyngeal Cancer Incidence in the United States. J. Clin. Oncol. 2011, 29, 4294-4301. [CrossRef] [PubMed]

23. Mehanna, H.; Beech, T.; Nicholson, T.; El-Hariry, I.; McConkey, C.; Paleri, V.; Roberts, S. Prevalence of human papillomavirus in oropharyngeal and nonoropharyngeal head and neck cancer-systematic review and meta-analysis of trends by time and region. Head Neck 2013, 35, 747-755. [CrossRef] [PubMed]

24. No, J.H.; Sung, M.-W.; Hah, J.H.; Choi, S.H.; Lee, M.-C.; Kim, H.S.; Song, Y.-S. Prevalence and prognostic value of human papillomavirus genotypes in tonsillar squamous cell carcinoma: A Korean multicenter study. Cancer 2015, 121, 535-544. [CrossRef]

25. Maruyama, H.; Yasui, T.; Ishikawa-Fujiwara, T.; Morii, E.; Yamamoto, Y.; Yoshii, T.; Takenaka, Y.; Nakahara, S.; Todo, T.; Hongyo, T.; et al. Human papillomavirus and p53 mutations in head and neck squamous cell carcinoma among Japanese population Cancer Sci. 2014, 105, 409-417. [CrossRef] [PubMed]

26. Lam, E.W.H.; Chan, J.Y.-W.; Chan, A.B.W.; Ng, C.S.; Lo, S.T.H.; Lam, V.S.C.; Chan, M.M.H.; Ngai, C.M.; Vlantis, A.; Ma, R.K.H.; et al. Prevalence, Clinicopathological Characteristics, and Outcome of Human Papillomavirus \& Associated Oropharyngeal Cancer in Southern Chinese Patients. Cancer Epidemiol. Biomark. Prev. 2016, 25, 165-173. [CrossRef]

27. Lorenzatti Hiles, G.; Chang, K.P.; Bellile, E.L.; Wang, C.I.; Yen, W.C.; Goudsmit, C.M.; Briggs, H.L.; Thomas, T.B.; Peters, L.; Afsari, M.A.; et al. Understanding the impact of high-risk human papillomavirus on oropharyngeal squamous cell carcinomas in Taiwan: A retrospective cohort study. PLoS ONE 2021, 16, e0250530.

28. Pusztaszeri, M.P.; Faquin, W.C. Cytologic evaluation of cervical lymph node metastases from cancers of unknown primary origin. Semin. Diagn. Pathol. 2015, 32, 32-41. [CrossRef] 
29. Hou, Y.; Chaudhary, S.; Shen, R.; Li, Z. Fine-needle aspiration of cervical lymph nodes yields adequate materials for accurate HPV testing in metastatic head and neck squamous cell carcinomas. Diagn. Cytopathol. 2016, 44, 792-798. [CrossRef]

30. Deschler, D.G.; Richmon, J.D.; Khariwala, S.S.; Ferris, R.L.; Wang, M.B. The "New" Head and Neck Cancer Patient-Young, Nonsmoker, Nondrinker, and HPV Positive. Otolaryngol. Neck Surg. 2014, 151, 375-380. [CrossRef]

31. Gillison, M.L.; D'Souza, G.; Westra, W.; Sugar, E.; Xiao, W.; Begum, S.; Viscidi, R. Distinct Risk Factor Profiles for Human Papillomavirus Type 16-Positive and Human Papillomavirus Type 16-Negative Head and Neck Cancers. J. Natl. Cancer Inst. 2008, 100, 407-420. [CrossRef]

32. Schroeder, L.; Boscolo-Rizzo, P.; Cin, E.D.; Romeo, S.; Baboci, L.; Dyckhoff, G.; Hess, J.; Lucena-Porcel, C.; Byl, A.; Becker, N.; et al. Human papillomavirus as prognostic marker with rising prevalence in neck squamous cell carcinoma of unknown primary: A retrospective multicentre study. Eur. J. Cancer 2017, 74, 73-81. [CrossRef]

33. Krane, J.F. Role of Cytology in the Diagnosis and Management of HPV-Associated Head and Neck Carcinoma. Acta Cytol. 2013, 57, 117-126. [CrossRef]

34. Fu, T.S.; Foreman, A.; Goldstein, D.P.; De Almeida, J.R. The role of transoral robotic surgery, transoral laser microsurgery, and lingual tonsillectomy in the identification of head and neck squamous cell carcinoma of unknown primary origin: A systematic review. J. Otolaryngol. Head Neck Surg. 2016, 45, 1-10. [CrossRef] [PubMed]

35. Larsen, C.G.; Jensen, D.H.; Carlander, A.-L.F.; Kiss, K.; Andersen, L.; Olsen, C.H.; Andersen, E.; Garnæs, E.; Cilius, F.; Specht, L.; et al. Novel nomograms for survival and progression in HPV + and HPV - oropharyngeal cancer: A population-based study of 1,542 consecutive patients. Oncotarget 2016, 7, 71761-71772. [CrossRef] [PubMed]

36. Fotopoulos, G.; Pavlidis, N. The role of human papilloma virus and p16 in occult primary of the head and neck: A comprehensive review of the literature. Oral Oncol. 2015, 51, 119-123. [CrossRef] [PubMed]

37. Begum, S.; Cao, D.; Gillison, M.; Zahurak, M.; Westra, W.H. Tissue Distribution of Human Papillomavirus 16 DNA Integration in Patients with Tonsillar Carcinoma. Clin. Cancer Res. 2005, 11, 5694-5699. [CrossRef] [PubMed]

38. Tommasino, M. The human papillomavirus family and its role in carcinogenesis. Semin. Cancer Biol. 2014, 26, 13-21. [CrossRef]

39. Dalianis, T. Human papillomavirus and oropharyngeal cancer, the epidemics, and significance of additional clinical biomarkers for prediction of response to therapy (Review). Int. J. Oncol. 2014, 44, 1799-1805. [CrossRef] [PubMed]

40. Lydiatt, W.M.; Patel, S.G.; O'Sullivan, B.; Brandwein, M.S.; Ridge, J.A.; Migliacci, J.C.; Loomis, A.M.; Shah, J.P. Head and neck cancers-major changes in the American Joint Committee on cancer eighth edition cancer staging manual. CA A Cancer J. Clin. 2017, 67, 122-137. [CrossRef] [PubMed]

41. Amin, M.B.; Greene, F.L.; Edge, S.B.; Compton, C.C.; Gershenwald, J.E.; Brookland, R.K.; Meyer, L.; Gress, D.M.; Byrd, D.R.; Winchester, D.P. The Eighth Edition AJCC Cancer Staging Manual: Continuing to build a bridge from a population-based to a more "personalized" approach to cancer staging. CA A Cancer J. Clin. 2017, 67, 93-99. [CrossRef] [PubMed]

42. Mork, J.; Lie, A.K.; Glattre, E.; Clark, S.; Hallmans, G.; Jellum, E.; Koskela, P.; Møller, B.; Pukkala, E.; Schiller, J.T.; et al. Human Papillomavirus Infection as a Risk Factor for Squamous-Cell Carcinoma of the Head and Neck. N. Engl. J. Med. 2001, 344, 1125-1131. [CrossRef] [PubMed]

43. Cao, D.; Begum, S.; Ali, S.Z.; Westra, W.H. Expression of p16 in benign and malignant cystic squamous lesions of the neck. Hum. Pathol. 2010, 41, 535-539. [CrossRef]

44. Chernock, R.D.; Lewis, J.S. Approach to Metastatic Carcinoma of Unknown Primary in the Head and Neck: Squamous Cell Carcinoma and Beyond. Head Neck Pathol. 2015, 9, 6-15. [CrossRef] [PubMed]

45. Rusthoven, K.E.; Koshy, M.; Paulino, A.C. The role of fluorodeoxyglucose positron emission tomography in cervical lymph node metastases from an unknown primary tumor. Cancer 2004, 101, 2641-2649. [CrossRef]

46. Williams, R.; Lee, N.W.; Elzey, B.D.; Anderson, M.E.; Hostager, B.S.; Lee, J.H. Preclinical models of HPV+ and HPV- HNSCC in mice: An immune clearance of HPV+ HNSCC. Head Neck 2009, 31, 911-918. [CrossRef] [PubMed]

47. Sivars, L.; Landin, D.; Grün, N.; Vlastos, A.; Marklund, L.; Nordemar, S.; Ramqvist, T.; Munck-Wikland, E.; Näsman, A.; Dalianis, T. Validation of Human Papillomavirus as a Favourable Prognostic Marker and Analysis of CD8+ Tumour-infiltrating Lymphocytes and Other Biomarkers in Cancer of Unknown Primary in the Head and Neck Region. Anticancer Res. 2017, 37, 665-673. [CrossRef] [PubMed]

48. Nordfors, C.; Grün, N.; Tertipis, N.; Ährlund-Richter, A.; Haeggblom, L.; Sivars, L.; Du, J.; Nyberg, T.; Marklund, L.; MunckWikland, E.; et al. CD8+ and CD4+ tumour infiltrating lymphocytes in relation to human papillomavirus status and clinical outcome in tonsillar and base of tongue squamous cell carcinoma. Eur. J. Cancer 2013, 49, 2522-2530. [CrossRef] [PubMed]

49. Näsman, A.; Romanitan, M.; Nordfors, C.; Grün, N.; Johansson, H.; Hammarstedt, L.; Marklund, L.; Munck-Wikland, E.; Dalianis, T.; Ramqvist, T. Tumor Infiltrating CD8+ and Foxp3+ Lymphocytes Correlate to Clinical Outcome and Human Papillomavirus (HPV) Status in Tonsillar Cancer. PLoS ONE 2012, 7, e38711. [CrossRef] [PubMed]

50. Phillips, D.H. Smoking-related DNA and protein adducts in human tissues. Carcinogenesis 2002, 23, 1979-2004. [CrossRef] [PubMed]

51. Liu, Z.; Liu, H.; Gao, F.; Dahlstrom, K.; Sturgis, E.M.; Wei, Q. Reduced DNA double-strand break repair capacity and risk of squamous cell carcinoma of the head and neck-A case-control study. DNA Repair 2016, 40, 18-26. [CrossRef] [PubMed]

52. Yasui, T.; Morii, E.; Yamamoto, Y.; Yoshii, T.; Takenaka, Y.; Nakahara, S.; Todo, T.; Inohara, H. Human Papillomavirus and Cystic Node Metastasis in Oropharyngeal Cancer and Cancer of Unknown Primary Origin. PLoS ONE 2014, 9, e95364. [CrossRef] [PubMed] 
53. Knoepp, S.M.; Roh, M.H. Ancillary techniques on direct-smear aspirate slides. Cancer Cytopathol. 2013, 121, 120-128. [CrossRef] [PubMed]

54. Novoa, E.; Gürtler, N.; Arnoux, A.; Kraft, M. Role of ultrasound-guided core-needle biopsy in the assessment of head and neck lesions: A meta-analysis and systematic review of the literature. Head Neck 2012, 34, 1497-1503. [CrossRef] [PubMed]

55. Begum, S.; Gillison, M.L.; Nicol, T.L.; Westra, W.H. Detection of Human Papillomavirus-16 in Fine-Needle Aspirates to Determine Tumor Origin in Patients with Metastatic Squamous Cell Carcinoma of the Head and Neck. Clin. Cancer Res. 2007, 13, 1186-1191. [CrossRef] [PubMed]

56. Grimes, R.; Garcia-Buitrago, M.T.; Jorda, M.; Ganjei-Azar, P.; Ferrell, A.; Gomez-Fernandez, C. p16INKa Immunocytochemistry in Fine-Needle Aspiration Cytology Smears of Metastatic Head and Neck Squamous Cell Carcinoma. Acta Cytol. 2013, 57 , 33-37. [CrossRef]

57. Jakscha, J.; Zlobec, I.; Storck, C.; Obermann, E.C.; Tornillo, L.; Terracciano, L.M.; Fischer, C.A. The clinical impact of p16 status in fine-needle aspirates of cervical lymph node metastasis of head and neck squamous cell carcinomas. Eur. Arch. Oto-Rhino-Laryngol. 2013, 270, 661-667. [CrossRef] [PubMed]

58. Zhang, M.Q.; Davila, R.M.; El-Mofty, S.K. Detection of human papillomavirus-related squamous cell carcinoma cytologically and by in situ hybridization in fine-needle aspiration biopsies of cervical metastasis. Cancer 2008, 114, 118-123. [CrossRef]

59. Boscolo-Rizzo, P.; Schroeder, L.; Romeo, S.; Pawlita, M. The prevalence of human papillomavirus in squamous cell carcinoma of unknown primary site metastatic to neck lymph nodes: A systematic review. Clin. Exp. Metastasis 2015, 32, 835-845. [CrossRef] [PubMed]

60. Aro, K.; Bäck, L.; Mäkitie, A.; Tapiovaara, L. An evaluation of the diagnostic methods in head and neck cancer of unknown primary site. Acta Oto-Laryngol. 2018, 138, 930-936. [CrossRef] [PubMed]

61. Daneshpajouhnejad, P.; Miller, J.A.; Maleki, Z. Diagnostic utility of high-risk human papillomavirus mRNA in situ hybridisation in squamous cell carcinoma of unknown primary in the head and neck and implementing American Society of Clinical Oncology guideline recommendations. Cytopathology 2020, 31, 547-554. [CrossRef]

62. Holmes, B.J.; Westra, W.H. The expanding role of cytopathology in the diagnosis of HPV-related squamous cell carcinoma of the head and neck. Diagn. Cytopathol. 2014, 42, 85-93. [CrossRef] [PubMed]

63. Nauta, I.H.; Rietbergen, M.M.; van Bokhoven, A.A.J.D.; Bloemena, E.; Lissenberg-Witte, B.I.; Heideman, D.A.M.; de Jong, R.J.B.; Brakenhoff, R.H.; Leemans, C.R. Evaluation of the eighth TNM classification on p16-positive oropharyngeal squamous cell carcinomas in the Netherlands and the importance of additional HPV DNA testing. Ann. Oncol. 2018, 29, 1273-1279. [CrossRef] [PubMed]

64. Durmus, K.; Rangarajan, S.V.; Old, M.O.; Agrawal, A.; Teknos, T.N.; Ozer, E. Transoral robotic approach to carcinoma of unknown primary. Head Neck 2013, 36, 848-852. [CrossRef]

65. Rasmussen, J.H.; Grønhøj, C.; Håkansson, K.; Friborg, J.; Andersen, E.; Lelkaitis, G.; Klussmann, J.P.; Wittekindt, C.; Wagner, S.; Vogelius, I.R.; et al. Risk profiling based on p16 and HPV DNA more accurately predicts location of disease relapse in patients with oropharyngeal squamous cell carcinoma. Ann. Oncol. 2019, 30, 629-636. [CrossRef] [PubMed]

66. Zhu, L.; Wang, N. 18F-fluorodeoxyglucose positron emission tomography-computed tomography as a diagnostic tool in patients with cervical nodal metastases of unknown primary site: A meta-analysis. Surg. Oncol. 2013, 22, 190-194. [CrossRef]

67. Liu, Y. FDG PET/CT for metastatic squamous cell carcinoma of unknown primary of the head and neck. Oral Oncol. 2019, 92, 46-51. [CrossRef]

68. Noij, D.P.; Martens, R.M.; Zwezerijnen, B.; Koopman, T.; de Bree, R.; Hoekstra, O.S.; de Graaf, P.; Castelijns, J.A. Diagnostic value of diffusion-weighted imaging and 18F-FDG-PET/CT for the detection of unknown primary head and neck cancer in patients presenting with cervical metastasis. Eur. J. Radiol. 2018, 107, 20-25. [CrossRef]

69. Ofo, E.; Spiers, H.; Kim, D.; Duvvuri, U. Transoral Robotic Surgery and the Unknown Primary. ORL 2018, 80, 148-155. [CrossRef] [PubMed]

70. Kwee, T.C.; Kwee, R.M. Combined FDG-PET/CT for the detection of unknown primary tumors: Systematic review and meta-analysis. Eur. Radiol. 2008, 19, 731-744. [CrossRef] [PubMed]

71. Rumboldt, Z.; Gordon, L.; Bonsall, R.; Ackermann, S. Imaging in head and neck cancer. Curr. Treat. Options Oncol. 2006, 7, 23-34. [CrossRef] [PubMed]

72. Hatten, K.M.; O’Malley, B.W.; Bur, A.; Patel, M.R.; Rassekh, C.H.; Newman, J.G.; Cannady, S.B.; Chalian, A.A.; Hodnett, B.L.; Lin, A.; et al. Transoral Robotic Surgery-Assisted Endoscopy With Primary Site Detection and Treatment in Occult Mucosal Primaries. JAMA Otolaryngol. Head Neck Surg. 2017, 143, 267-273. [CrossRef] [PubMed]

73. Khan, N.; Kass, J.; Teng, M.; Miles, B.; Genden, E. Transoral Robotic-Assisted Resection Approach for Identifying Unknown Primaries of the Head and Neck. Int. J. Radiat. Oncol. 2016, 94, 893. [CrossRef]

74. Krishnan, S.; Connell, J.; Ofo, E. Transoral robotic surgery base of tongue mucosectomy for head and neck cancer of unknown primary. ANZ J. Surg. 2016, 87, E281-E284. [CrossRef] [PubMed]

75. Cantrell, S.C.; Peck, B.W.; Li, G.; Wei, Q.; Sturgis, E.M.; Ginsberg, L.E. Differences in Imaging Characteristics of HPV-Positive and HPV-Negative Oropharyngeal Cancers: A Blinded Matched-Pair Analysis. Am. J. Neuroradiol. 2013, 34, 2005-2009. [CrossRef] [PubMed] 
76. Fujima, N.; Andreu-Arasa, V.C.; Meibom, S.K.; Mercier, G.A.; Truong, M.T.; Sakai, O. Prediction of the human papillomavirus status in patients with oropharyngeal squamous cell carcinoma by FDG-PET imaging dataset using deep learning analysis: A hypothesis-generating study. Eur. J. Radiol. 2020, 126, 108936. [CrossRef] [PubMed]

77. Lang Kuhs, K.A.; Wood, C.B.; Wiggleton, J.; Aulino, J.M.; Latimer, B.; Smith, D.K.; Bender, N.; Rohde, S.; Mannion, K.; Kim, Y.; et al. Transcervical sonography and human papillomavirus 16 E6 antibodies are sensitive for the detection of oropharyngeal cancer. Cancer 2020, 126, 2658-2665. [CrossRef]

78. Geltzeiler, M.; Doerfler, S.; Turner, M.; Albergotti, W.G.; Kubik, M.; Kim, S.; Ferris, R.; Duvvuri, U. Transoral robotic surgery for management of cervical unknown primary squamous cell carcinoma: Updates on efficacy, surgical technique and margin status. Oral Oncol. 2017, 66, 9-13. [CrossRef] [PubMed]

79. Sokoya, M.; Chowdhury, F.; Kadakia, S.; Ducic, Y. Combination of panendoscopy and positron emission tomography/computed tomography increases detection of unknown primary head and neck carcinoma. Laryngoscope 2018, 128, 2573-2575. [CrossRef] [PubMed]

80. Di Maio, P.; Iocca, O.; De Virgilio, A.; Ferreli, F.; Cristalli, G.; Pellini, R.; Golusinski, P.; Ricci, G.; Spriano, G. Role of palatine tonsillectomy in the diagnostic workup of head and neck squamous cell carcinoma of unknown primary origin: A systematic review and meta-analysis. Head Neck 2019, 41, 1112-1121. [CrossRef]

81. Lee, M.Y.; Fowler, N.; Adelstein, D.; Koyfman, S.; Prendes, B.; Burkey, B.B. Detection and Oncologic Outcomes of Head and Neck Squamous Cell Carcinoma of Unknown Primary Origin. Anticancer Res. 2020, 40, 4207-4214. [CrossRef] [PubMed]

82. Tanzler, E.D.; Amdur, R.J.; Morris, C.G.; Werning, J.W.; Mendenhall, W.M. Challenging the need for random directed biopsies of the nasopharynx, pyriform sinus, and contralateral tonsil in the workup of unknown primary squamous cell carcinoma of the head and neck. Head Neck 2016, 38, 578-581. [CrossRef]

83. Di Maio, P.; Iocca, O.; De Virgilio, A.; Giudice, M.; Pellini, R.; D’Ascanio, L.; Golusiński, P.; Ricci, G.; Spriano, G. Narrow band imaging in head and neck unknown primary carcinoma: A systematic review and meta-analysis. Laryngoscope 2020, 130, 1692-1700. [CrossRef] [PubMed]

84. Sansoni, E.R.; Gross, N.D. The Role of Transoral Robotic Surgery in the Management of Oropharyngeal Squamous Cell Carcinoma: A Current Review. Curr. Oncol. Rep. 2015, 17, 1-7. [CrossRef] [PubMed]

85. Chen, M.M.; Roman, S.A.; Kraus, D.H.; Sosa, J.A.; Judson, B.L. Transoral Robotic Surgery. Otolaryngol. Neck Surg. 2014, 150, 968-975. [CrossRef]

86. Farooq, S.; Khandavilli, S.; Dretzke, J.; Moore, D.; Nankivell, P.C.; Sharma, N.; de Almeida, J.R.; Winter, S.; Simon, C.; Paleri, V.; et al. Transoral tongue base mucosectomy for the identification of the primary site in the work-up of cancers of unknown origin: Systematic review and meta-analysis. Oral Oncol. 2019, 91, 97-106. [CrossRef]

87. Meccariello, G.; Cammaroto, G.; Ofo, E.; Calpona, S.; Parisi, E.; D’Agostino, G.; Gobbi, R.; Firinu, E.; Bellini, C.; De Vito, A.; et al. The emerging role of trans-oral robotic surgery for the detection of the primary tumour site in patients with head-neck unknown primary cancers: A meta-analysis. Auris Nasus Larynx 2019, 46, 663-671. [CrossRef]

88. Van Weert, S.; Rijken, J.A.; Plantone, F.; Bloemena, E.; Vergeer, M.R.; Witte, B.I.L.; Leemans, C.R. A systematic review on Transoral robotic surgery (TORS) for carcinoma of unknown primary origin: Has tongue base mucosectomy become indispensable? Clin. Otolaryngol. 2020, 45, 732-738. [CrossRef] [PubMed]

89. Kubik, M.W.; Channir, H.I.; Rubek, N.; Kim, S.; Ferris, R.L.; von Buchwald, C.; Duvvuri, U. TORS Base-of-Tongue Mucosectomy in Human Papilloma Virus-Negative Carcinoma of Unknown Primary. Laryngoscope 2021, 131, 78-81. [CrossRef]

90. Nilsson, J.S.; Wahlberg, P.; Greiff, L. Transoral robotic surgery in the management of head and neck squamous cell cancer with unknown primary. Acta Oto-Laryngol. 2019, 140, 85-88. [CrossRef] [PubMed]

91. Patel, S.A.; Parvathaneni, A.; Parvathaneni, U.; Houlton, J.J.; Karni, R.J.; Liao, J.J.; Futran, N.D.; Méndez, E. Post-operative therapy following transoral robotic surgery for unknown primary cancers of the head and neck. Oral Oncol. 2017, 72, 150-156. [CrossRef]

92. Saber, C.N.; Grønhøj, C.; Jensen, D.H.; Nørregaard, C.; Carlander, A.; Garnæs, E.; Kiss, K.; Specht, L.; von Buchwald, C. Synchronous, bilateral tonsillar carcinomas: Patient characteristics and human papillomavirus genotypes. Oral Oncol. 2017, 74, 105-110. [CrossRef] [PubMed]

93. Milliet, F.; Bozec, A.; Schiappa, R.; Viotti, J.; Modesto, A.; Dassonville, O.; Poissonnet, G.; Guelfucci, B.; Bizeau, A.; Vergez, S.; et al. Synchronous primary neoplasia in patients with oropharyngeal cancer: Impact of tumor HPV status. A GETTEC multicentric study. Oral Oncol. 2021, 112, 105041. [CrossRef] [PubMed]

94. Strober, W.; Shishido, S.; Wood, B.; Lewis, J.S.; Kuhs, K.; Ferris, R.; Faden, D.L. Two for the price of one: Prevalence, demographics and treatment implications of multiple HPV mediated Head and Neck Cancers. Oral Oncol. 2020, 100, 104475. [CrossRef] [PubMed]

95. Winter, S.C.; Ofo, E.; Meikle, D.; Silva, P.; Fraser, L.; O’Hara, J.; Kim, D.; Robinson, M.; Paleri, V. Trans-oral robotic assisted tongue base mucosectomy for investigation of cancer of unknown primary in the head and neck region. The UK experience. Clin. Otolaryngol. 2017, 42, 1247-1251. [CrossRef] [PubMed]

96. Axelsson, L.; Nyman, J.; Haugen-Cange, H.; Bove, M.; Johansson, L.; De Lara, S.; Kovács, A.; Hammerlid, E. Prognostic factors for head and neck cancer of unknown primary including the impact of human papilloma virus infection. J. Otolaryngol. Head Neck Surg. 2017, 46, 1-10. [CrossRef]

97. Coordes, A.; Lenz, K.; Qian, X.; Lenarz, M.; Kaufmann, A.M.; Albers, A.E. Meta-analysis of survival in patients with HNSCC discriminates risk depending on combined HPV and p16 status. Eur. Arch. Oto-Rhino-Laryngol. 2016, 273, 2157-2169. [CrossRef] 
98. Davis, K.S.; Byrd, J.K.; Mehta, V.; Chiosea, S.I.; Kim, S.; Ferris, R.L.; Johnson, J.T.; Duvvuri, U. Occult primary head and neck squamous cell carcinoma: Utility of discovering primary lesions. Otolaryngol. Head Neck Surg. 2014, 151, 272-278. [CrossRef]

99. Mehta, V.; Johnson, P.; Tassler, A.; Kim, S.; Ferris, R.L.; Nance, M.; Johnson, J.T.; Duvvuri, U. A new paradigm for the diagnosis and management of unknown primary tumors of the head and neck: A role for transoral robotic surgery. Laryngoscope 2013, 123, 146-151. [CrossRef]

100. Herruer, J.M.; Taylor, S.M.; Mackay, C.A.; Ubayasiri, K.M.; Lammers, D.; Kuta, V.; Bullock, M.J.; Corsten, M.J.; Trites, J.R.B.; Rigby, M.H. Intraoperative Primary Tumor Identification and Margin Assessment in Head and Neck Unknown Primary Tumors. Otolaryngol. Neck Surg. 2020, 162, 313-318. [CrossRef]

101. Kuta, V.; Williams, B.; Rigby, M.; Hart, R.; Trites, J.; Mackay, C.; Taylor, S.M. Management of head and neck primary unknown squamous cell carcinoma using combined positron emission tomography-computed tomography and transoral laser microsurgery. Laryngoscope 2018, 128, 2307-2311. [CrossRef]

102. Graboyes, E.M.; Sinha, P.; Thorstad, W.L.; Rich, J.T.; Haughey, B.H. Management of human papillomavirus-related unknown primaries of the head and neck with a transoral surgical approach. Head Neck 2015, 37, 1603-1611. [CrossRef]

103. Grewal, A.S.; Rajasekaran, K.; Cannady, S.B.; Chalian, A.A.; Ghiam, A.F.; Lin, A.; Livolsi, V.; Lukens, J.N.; Mitra, N.; Montone, K.T.; et al. Pharyngeal-sparing radiation for head and neck carcinoma of unknown primary following TORS assisted work-up. Laryngoscope 2020, 130, 691-697. [CrossRef]

104. Kharytaniuk, N.; Molony, P.; Boyle, S.; O'Leary, G.; Werner, R.; Heffron, C.; Feeley, L.; Sheahan, P. Association of Extracapsular Spread with Survival According to Human Papillomavirus Status in Oropharynx Squamous Cell Carcinoma and Carcinoma of Unknown Primary Site. JAMA Otolaryngol. Neck Surg. 2016, 142, 683. [CrossRef]

105. Maxwell, J.H.; Ferris, R.L.; Ms, W.G.; Ms, D.C.; Mehta, V.; Kim, S.; Myers, E.N.; Johnson, J.; Chiosea, S. Extracapsular spread in head and neck carcinoma: Impact of site and human papillomavirus status. Cancer 2013, 119, 3302-3308. [CrossRef]

106. Sinha, P.; Lewis, J.S.; Piccirillo, J.F.; Kallogjeri, D.; Haughey, B.H. Extracapsular spread and adjuvant therapy in human papillomavirus-related, p16-positive oropharyngeal carcinoma. Cancer 2012, 118, 3519-3530. [CrossRef] [PubMed]

107. Cheraghlou, S.; Torabi, S.J.; Husain, Z.A.; Otremba, M.D.; Osborn, H.A.; Mehra, S.; Yarbrough, W.G.; Burtness, B.A.; Judson, B.L. HPV status in unknown primary head and neck cancer: Prognosis and treatment outcomes. Laryngoscope 2019, 129, 684-691. [CrossRef]

108. Baseman, J.G.; Koutsky, L.A. The epidemiology of human papillomavirus infections. J. Clin. Virol. 2005, 32, 16-24. [CrossRef] [PubMed]

109. Kjaer, S.K.; van den Brule, A.J.C.; Paull, G.; Svare, E.I.; Sherman, M.E.; Thomsen, B.L.; Suntum, M.; E Bock, J.; Poll, P.A.; Meijer C.J.L.M. Type specific persistence of high risk human papillomavirus (HPV) as indicator of high grade cervical squamous intraepithelial lesions in young women: Population based prospective follow up study. BMJ 2002, 325, 572. [CrossRef] [PubMed]

110. Grønhøj, C.; Jakobsen, K.K.; Kjær, E.; Friborg, J.; von Buchwald, C. Comorbidity in HPV+ and HPV- oropharyngeal cancer patients: A population-based, case-control study. Oral Oncol. 2019, 96, 1-6. [CrossRef]

111. Eytan, D.F.; ScM, A.L.B.; Eisele, D.W.; Fakhry, C. Prevalence of comorbidities and effect on survival in survivors of human papillomavirus-related and human papillomavirus-unrelated head and neck cancer in the United States. Cancer 2019, 125, 249-260. [CrossRef]

112. Karni, R.J.; Rich, J.T.; Sinha, P.; Haughey, B.H. Transoral laser microsurgery: A new approach for unknown primaries of the head and neck. Laryngoscope 2011, 121, 1194-1201. [CrossRef]

113. Durmus, K.; Patwa, H.S.; Gokozan, H.N.; Kucur, C.; Teknos, T.N.; Agrawal, A.; Old, M.O.; Ozer, E. Functional and quality-of-life outcomes of transoral robotic surgery for carcinoma of unknown primary. Laryngoscope 2014, 124, 2089-2095. [CrossRef]

114. Ozbay, I.; Yumusakhuylu, A.C.; Sethia, R.; Wei, L.; Old, M.; Agrawal, A.; Teknos, T.; Ozer, E. One-year quality of life and functional outcomes of transoral robotic surgery for carcinoma of unknown primary. Head Neck 2017, 39, 1596-1602. [CrossRef] [PubMed]

115. Topf, M.C.; Vo, A.; Tassone, P.; Shumrick, C.; Luginbuhl, A.; Cognetti, D.M.; Curry, J.M. Unplanned readmission following transoral robotic surgery. Oral Oncol. 2017, 75, 127-132. [CrossRef] [PubMed]

116. Larsen, M.H.H.; Scott, S.I.; Kehlet, H.; Von Buchwald, C. Days alive and out of hospital a validated patient-centred outcome to be used for patients undergoing transoral robotic surgery: Protocol and perspectives. Acta Oto-Laryngol. 2021, 141, 95-98. [CrossRef] [PubMed] 